\title{
Design of Experiments Application for Machining Process Analyse
}

\author{
L'. JAVOREK, M. VARGOVSKÁ \\ Technical University in Zvolen, Faculty of Technology, Department of Manufacturing and Automation \\ Technology, lubomir.javorek@tuzvo.sk \\ Technical University in Zvolen, Faculty of Technology, Department of Manufacturing and Automation \\ Technology, maria.vargovska@tuzvo.sk
}

Abstract. In this contribution are results from machining of the aluminium alloy by spiral router. The experiment was designed as full 3 - factors and 2-levels process and for evaluation of input factors to output parameters - Fx and Fy components were used Paret's diagram and Lorentz's line. The input parameters were: revolution speed (4000/min. and 6000/min.), working engagement of a cutting edge (depth of cut) $a_{e}(1 \mathrm{~mm}$ and $3 \mathrm{~mm}$ ), back engagement of a cutting edge (with of cut) $a_{p}(5 \mathrm{~mm}$ and $15 \mathrm{~mm}$ ) and down (climb) milling.

Keywords: machining, forces, design of experiments

\section{Introduction}

The creation of each product which is characterized by a shape, dimensions, surface parameters and that would be accepted by potential customer - it is the aim of every production process.

It means, that all parameters of product are defined by technical drawings and must be realized by acceptable setting of production process parameters (factors); for machining it is for example cutting speed, feed speed, revolutions, depth of cut, tool geometry etc. [1] offers very detail information of production process, i.e. the analyse of individual factors and its influence to process are the basic of controlling and the acceptable goal. The statistical methods must not be used for controlling only at the last stage of production, but they may by an efficient tool for setting or modification these factors before, or during process, but relevant values must be obtain earlier, usually from experiments.

Design of Experiment (DOE) is an experimental or analytical method that is commonly used to statistically signify the relationship between input parameters to output responses, where by a systematic way of planning of experiments (or production process), collection and analysis of data from real manufacturing process are executed. By [2], [3] DOE has wide applications especially in the field of science and engineering for the purpose of process optimization and development, process management and validation tests. [4] used CCR design with aim to find out the conditions of the controllable factors (quantity of solvent, cooling temperature, specific time frame of crushing) affecting the lacquer quality, i.e. smoothness of lacquer surface. [5] and [6] in their contributions present a study of the influence of cutting conditions on the cutting force components during face milling of steel. The two experimental 
plans, rotatable central composite design, together with Taguchi method were used parallel and results from both methods were compared. [7] were interested in chemical industry and they applied the fivelevel, four factor central composite rotatable design (CCRD) for evaluate the interactive effects of synthesis, reaction time, temperature, amount of enzyme and substrate molar ratio and to optimize the synthesis process of ester wax. [8] used CCR model during sawing of beech and established influence of rotary speed and feed speed to final force. The modern methods for quality managements, like Taguchi were used by [9] in welding technology for optimization of basic parameters of fusion arc welding, in grinding processes [10], very often in milling or routing [11]. Paper [12] presents two different optimal control strategies; one from them only considers the dynamic of the machine structure, the second one takes explicitly the process interaction into account. [13], which analysed problem of face-milling optimisation, the numerical model to optimise machining parameters (depth of cut, the sequence of depths) in multi pass processes. [14] used modern methods of experiments design in drilling of guns, [15] for mapping of drilling and tapping process to different materials (steel AISI H13 hardened to 48 $52 \mathrm{HRC}$ and AISI D2 hardened to 60-62 HRC were used) and [16] analysed drilling characteristics in polymeric composites. [17] used DOE for evaluation of thrust force. Application of central composite rotatable design / (CCRD) in mechanical processes and for predictive of force is presents in article from [18] and [19] used philosophy of CCRD in experiment focused to study of the effect of input parameters on removal rate for wire electric discharge machining of high strength low alloy steel; the surface roughness was out put parameter. Very similar application of Taguchi philosophy is public by [20], or [21]. [22] used CCR design of experiment for compare two different machining process of curved surfaces and [23] in their research used a lot of various statistical methods including central composite rotatable model for determine optimal cutting parameters in order to achieve minimal expenses or minimal production time. The very wide areas for using of modern statistical methods like design of experiments, factorial design with Taguchi's design or ANOVA analyses confirm [24] or [25], which used these methods in turning processes, or in powder technologies.

\section{Materials and methods}

The design of experiments and procedures are as follows:

- Definition of the problem and identification of main factors.

- Selection of response variables and selection of control parameters and their levels.

- Identification of control factor interactions.

- Selection of the orthogonal array and conducting the matrix experiments.

- Analysis of the data and prediction of optimum level for example manufacturing process.

\subsection{Application of DOE in routing, i.e. production process}

At present more and more thin wall elements from aluminium alloy are used in automotive or aerospace industry, where the conformity of real dimensions of workpiece with dimensions on technical drawings is inevitable for acceptance of producer for potential business. Deflection of any part on thin wall elements means that it is out of dimensions, shapes etc. The high value of force 
(forces) can be reason of this facts (faults, defects...), so that monitoring of force parameter may be way for increasing of production efficiency.

DOE method was used in routing of plate from aluminium alloy used in automotive and aerospace industry and the aim of experiment was to estimate the influence of variables on final force and its components. DOE was applied as a part of process considering a monitoring of process and to mark way for minimize of routed part deflection. Purpose was to determine key input factors and their optimal level for a machining process. We realized an experiment with 3 - factor and 2-level, where $\mathrm{n}$ factors are studied, each of them with 2 levels. Lower level is marked as -1 and upper level +1 . In this case the design of experiment involves all possible combinations of factors and their levels. The number of experiments $\mathrm{k}$ with $\mathrm{n}$ factors is $2 \mathrm{n}$. Design matrix represents all combination of possible experiments by using both levels of determined factors.
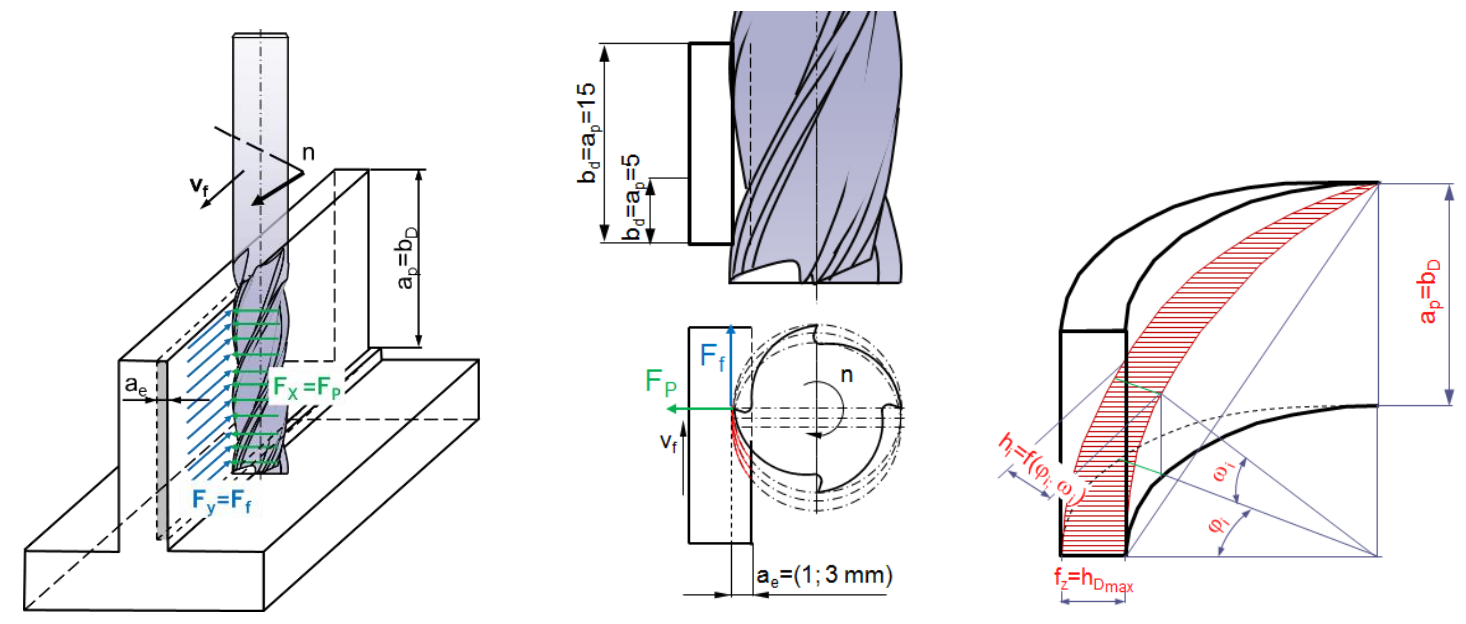

Figure 1. The scheme of machining (total view; zoom of contact "tool /piece; schape of chip)

As input factors with influence on output characteristics were determined the following factors and their levels:

- revolution speed: the lower limit $4000 \mathrm{rpm}$ and the upper limit $6000 \mathrm{rpm}$;

- working engagement of a cutting edge $\mathrm{a}_{\mathrm{e}}$ : the lower limit - $1 \mathrm{~mm}$; and the upper $-3 \mathrm{~mm}$;

- back engagement of a cutting edge $\mathrm{a}_{\mathrm{p}}$ : the lower limit $-5 \mathrm{~mm}$; and the upper $-15 \mathrm{~mm}$.

The independ parameters, symbols and limits of factors are displayed in table 1; codes of variables are mentioned in tab. 2. Individual experiments were realized in random order and each experiment was repeated 3 times.

\begin{tabular}{|c|c|c|c|c|c|c|}
\hline & \multirow[t]{2}{*}{ Factor } & \multirow[t]{2}{*}{ Units } & \multicolumn{2}{|c|}{ Symbols } & \multicolumn{2}{|c|}{ Limits of factors } \\
\hline & & & Original & Coded & Lower -1 & Upper +1 \\
\hline 1 & Revolutions & $1 / \mathrm{min}$. & $\mathrm{n}$ & A & 4000 & 6000 \\
\hline 2 & $\begin{array}{l}\text { Working engagement of a cutting edge } a_{\mathrm{e}} \\
\text { (depth of cut) }\end{array}$ & $\mathrm{mm}$ & $a_{e}$ & B & 1 & 3 \\
\hline 3 & $\begin{array}{l}\text { Back engagement of a cutting edge } a_{p} \\
\text { (with of cut) }\end{array}$ & $\mathrm{mm}$ & $a_{p}$ & C & 5 & 15 \\
\hline
\end{tabular}

Table 1. The marking of input factors 


\begin{tabular}{|c|c|c|c|c|c|c|c|c|c|c|}
\hline \multirow[t]{2}{*}{ Run } & \multirow{2}{*}{$\begin{array}{l}\text { Revolutions } \\
\text { (1/min.) } \\
\text { A }\end{array}$} & \multirow{2}{*}{$\begin{array}{c}\text { Working } \\
\text { engagement of } \\
\text { a cutting edge } \\
a_{e}(\mathrm{~mm}) \\
B\end{array}$} & \multirow{2}{*}{$\begin{array}{c}\text { Back } \\
\text { engagement } \\
\text { of a cutting } \\
\text { edge } a_{p}(\mathrm{~mm}) \\
C\end{array}$} & \multicolumn{7}{|c|}{ Codes of variables } \\
\hline & & & & $A$ & $B$ & $\mathrm{C}$ & $A B$ & $A C$ & $\mathrm{BC}$ & $A B C$ \\
\hline 1 & 4000 & 1 & 5 & -1 & -1 & -1 & +1 & +1 & +1 & -1 \\
\hline 2 & 4000 & 1 & 15 & -1 & -1 & +1 & +1 & -1 & -1 & +1 \\
\hline 3 & 4000 & 3 & 5 & -1 & +1 & -1 & -1 & +1 & -1 & +1 \\
\hline 4 & 4000 & 3 & 15 & -1 & +1 & +1 & -1 & -1 & +1 & -1 \\
\hline 5 & 6000 & 1 & 5 & +1 & -1 & -1 & -1 & -1 & +1 & +1 \\
\hline 6 & 6000 & 1 & 15 & +1 & -1 & +1 & -1 & +1 & -1 & -1 \\
\hline 7 & 6000 & 3 & 5 & +1 & +1 & -1 & +1 & -1 & -1 & -1 \\
\hline 8 & 6000 & 3 & 15 & +1 & +1 & +1 & +1 & +1 & +1 & +1 \\
\hline
\end{tabular}

Table 2. Design matrix for independent values

\section{Results}

All process of computing was realised by MS Excell software and output values are displayed in tables Tab.3 and Tab. 4.

\begin{tabular}{|c|c|c|c|c|c|c|c|c|c|c|c|c|c|c|}
\hline \multirow{2}{*}{ Run } & \multicolumn{2}{|c|}{ A } & \multicolumn{2}{|c|}{$B$} & \multicolumn{2}{|c|}{ C } & \multicolumn{2}{|c|}{$A B$} & \multicolumn{2}{|c|}{$A C$} & \multicolumn{2}{|c|}{$B C$} & \multicolumn{2}{|c|}{$A B C$} \\
\hline & -1 & +1 & -1 & +1 & -1 & +1 & -1 & +1 & \begin{tabular}{|l|}
-1 \\
\end{tabular} & +1 & -1 & +1 & \begin{tabular}{l|}
-1 \\
\end{tabular} & +1 \\
\hline 1 & 27.7 & & 27.7 & & 27.7 & & & 27.7 & & 27,7 & & 27,7 & 27,7 & \\
\hline 2 & 60.5 & & 60.5 & & & 60.5 & & 60.5 & 60.5 & & 60.5 & & & 60.5 \\
\hline 3 & 78.5 & & & 78.5 & 78.5 & & 78.5 & & & 78.5 & 78.5 & & & 78.5 \\
\hline 4 & 198.6 & & & 198.6 & & 198.6 & 198.6 & & 198.6 & & & 198.6 & 198.6 & \\
\hline 5 & & 21.2 & 21.2 & & 21.2 & & 21.2 & & 21.2 & & & 21.2 & & 21.2 \\
\hline 6 & & 43.5 & 43.5 & & & 43.5 & 43.5 & & & 43.5 & 43.5 & & 43.5 & \\
\hline 7 & & 56.8 & & 56.8 & 56.8 & & & 43.5 & 56.8 & & 56.8 & & 56.8 & \\
\hline 8 & & 145.4 & & 145.4 & & 145.4 & & 56.8 & & 145.4 & & 145.4 & & 145.4 \\
\hline AVG & 91.3 & 66.7 & 38.2 & 119.8 & 46.1 & 112.0 & 85.5 & 47.1 & 84.3 & 73.8 & 50.1 & \begin{tabular}{|l|}
98.2 \\
\end{tabular} & 81.7 & 76.4 \\
\hline Effect & -24 & 1.6 & 81 & 1.6 & & 5.9 & -3 & & -10 & 0.5 & 48 & & & \\
\hline
\end{tabular}

Table 3. Output characteristic for force component $F x$

\begin{tabular}{|c|c|c|c|c|c|c|r|r|r|r|r|r|r|r|}
\hline \multirow{2}{*}{ Run } & \multicolumn{2}{|c|}{ A } & \multicolumn{2}{|c|}{ B } & \multicolumn{2}{c|}{ C } & \multicolumn{2}{c|}{ AB } & \multicolumn{2}{c|}{ AC } & \multicolumn{2}{|c|}{ BC } & \multicolumn{2}{c|}{ ABC } \\
\cline { 2 - 17 } & -1 & +1 & -1 & +1 & -1 & +1 & -1 & +1 & -1 & +1 & -1 & +1 & -1 & +1 \\
\hline 1 & 23.2 & & 23.2 & & 23.2 & & & 23.2 & & 23.2 & & 23.2 & 23.2 & \\
\hline 2 & 60.5 & & 60.5 & & & 60.5 & & 60.5 & 60.5 & & 60.5 & & & 60.5 \\
\hline 3 & 44.2 & & & 44.2 & 44.2 & & 44.2 & & & 44.2 & 44.2 & & & 44.2 \\
\hline 4 & 128.9 & & & 128.9 & & 128.9 & 128.9 & & 128.9 & & & 128.9 & 128.9 & \\
\hline 5 & & 16.7 & 16.7 & & 16.7 & & 16.7 & & 16.7 & & & 16.7 & & 16.7 \\
\hline 6 & & 43.4 & 43.4 & & & 43.4 & 43.4 & & & 43.4 & 43.4 & & 43.4 & \\
\hline 7 & & 30.4 & & 30.4 & 30.4 & & & 30.4 & 30.4 & & 30.4 & & 30.4 & \\
\hline 8 & & 90.6 & & 90.6 & & 90.6 & & 90.6 & & 90.6 & & 90.6 & & 90.6 \\
\hline AVG & 64.2 & 45.3 & 36.0 & 73.5 & 28.6 & 80.9 & 58.3 & 51.2 & 59.1 & 50.4 & 44.6 & 64.9 & 56.5 & 53.0 \\
\hline Effect & -18.9 & \multicolumn{2}{|c|}{37.5} & 52.2 & -7.1 & -8.7 & 20.2 & & -3.4 \\
\hline
\end{tabular}

Table 4. Output characteristic for force component Fy 
The values from tables 3 and 4 and some actuarial (mathematical) operations were source for creation of bellow mentioned predictive equations for Fx.i and Fy.i; the results for all combinations of input values (see Tab. 2) are in Table 5.

$$
\begin{gathered}
F_{x, i}=79.07+(-24.61) \cdot A+81.60 \cdot B+65.92 \cdot C+(-38.37) \cdot A B+(-10.50) \cdot A C+48.08 \\
\cdot B C+(-5.26) \cdot A B C
\end{gathered}
$$

$$
\begin{gathered}
F_{y, i}=54.79-18.92 \cdot A+37.53 \cdot B+52.13 \cdot C-7.14 \cdot A B-8.77 \cdot A C+20.22 \cdot B C-3.45 \\
\cdot A B C
\end{gathered}
$$

\begin{tabular}{|l|l|l|l|l|l|l|l|l|}
\hline$F_{x, i}$ & $F_{x, 1}$ & $F_{x, 2}$ & $F_{x, 3}$ & $F_{x, 4}$ & $F_{x, 5}$ & $F_{x, 6}$ & $F_{x, 7}$ & $F_{x, 8}$ \\
\hline & -39.37 & 6.79 & 93.88 & 353.45 & -1.35 & 23.81 & -0.57 & 195.94 \\
\hline$F_{y, i}$ & $F_{y, 1}$ & $F_{y, 2}$ & $F_{y, 3}$ & $F_{y, 4}$ & $F_{y, 5}$ & $F_{y, 6}$ & $F_{y, 7}$ & $F_{y, 8}$ \\
\hline & -8.29 & 66.37 & 33.69 & 203.07 & -21.20 & 32.17 & 6.03 & 126.47 \\
\hline
\end{tabular}

The above mentioned mathematic formulas and results from Tab. 5 confirm that the worst combination (the most heavy conditions of machining) were in run 4. If we will compare for example experiment 4 and 8, i.e. ae and ap are the same, revolutions in experiment 8 are 1.5 times more, bur final force Fx,8 is 1.8 time less than Fx,4 . Very similar results valid for force Fy,8 and Fy, 4 .

If we will analyse the follows graphs (Fig. 2 and Fig.3) that illustrated influence of independed factors and their interaction to output parameter, Fx and Fy. than is evident, that from $80 \%$, the biggest influence have parameters B (working engagement of a cutting edge ae) and C (back engagement of a cutting edge ap).

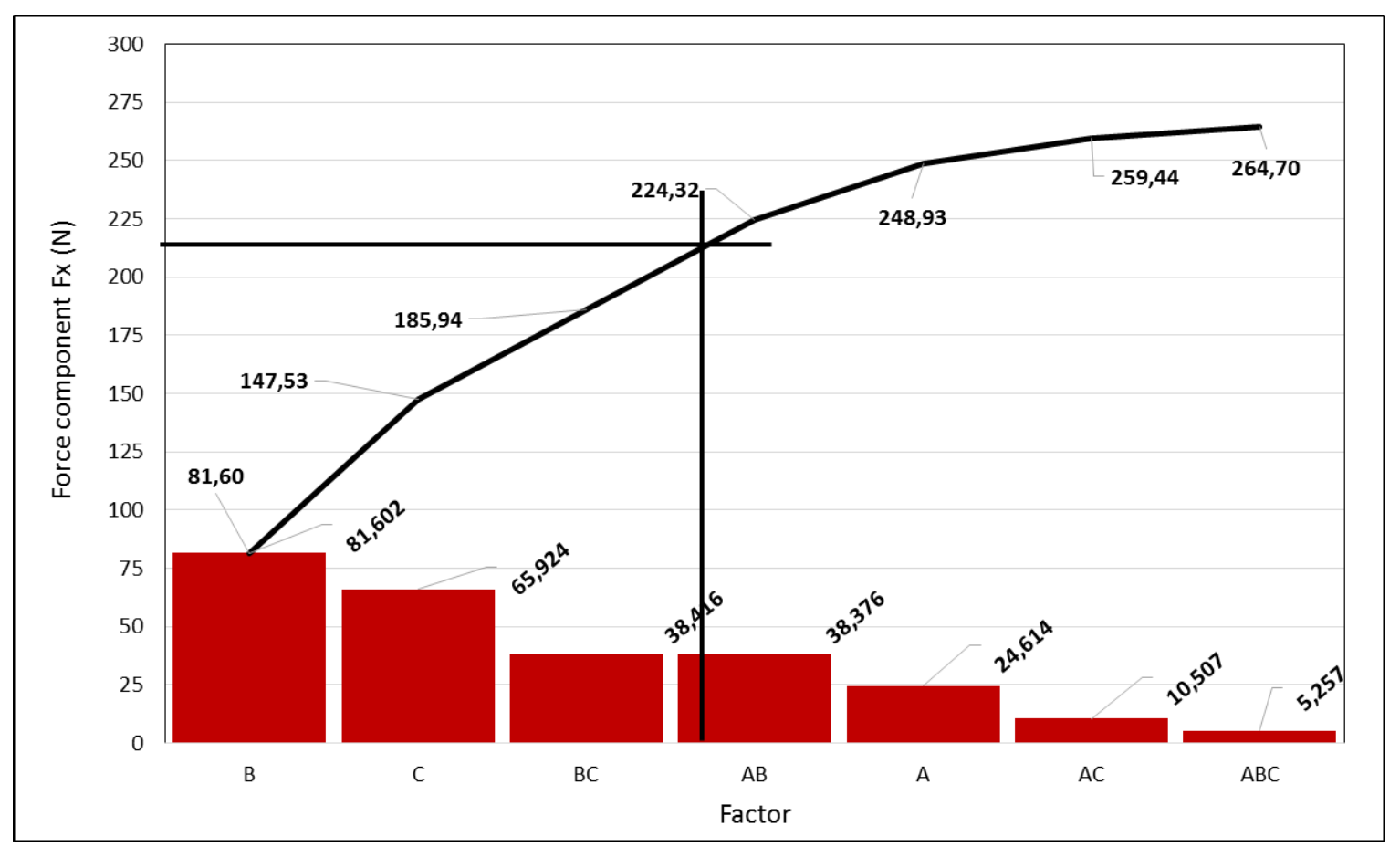

Figure 2. Paret's diagram and Lorentz's line for force component Fx 


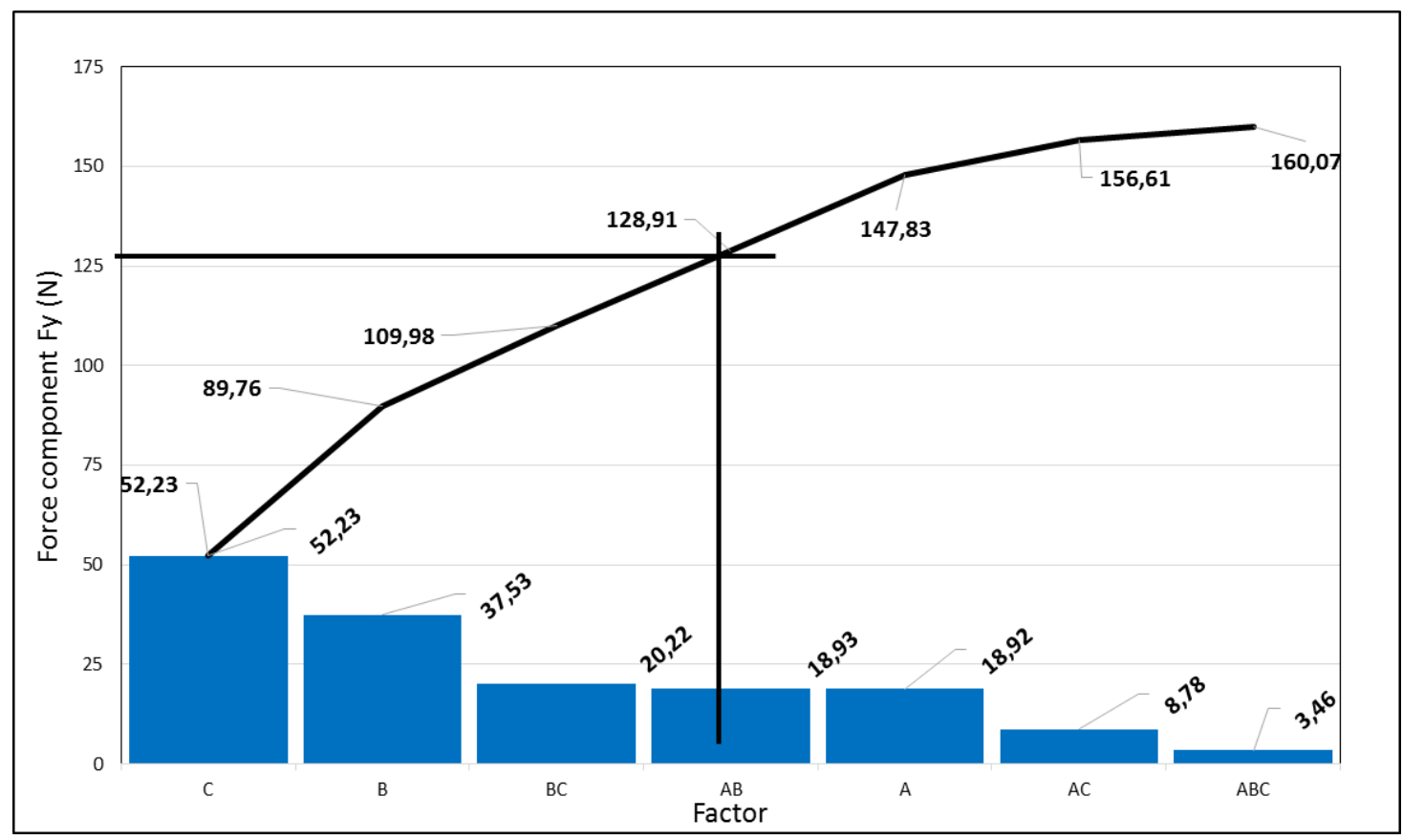

Figure 3. Paret's diagram and Lorentz's line for force component Fy

This paper has discussed the influence of cutting parameters like the cutting speed, working engagement of a cutting edge ae (depth of cut) and back engagement of a cutting edge ap (with of cut), respectively using design of experiment method for establish the influence of variables to the cutting force components in routing.

\section{Results and Discussion}

Regarding the results were found the most important parameter (respectively sequence of parameters) for the predictions of the force component Fx and Fy; in our case it is with of cut, very closely followed by depth of cut.

For force component Fx (only for ilustratration; all another conclusions are able from Tab.3 and Tabl.4), (rev. $4000 / \mathrm{min} .$, resp. $6000 / \mathrm{min} ., \mathrm{a}_{\mathrm{e}}=1 \mathrm{~mm}, \mathrm{a}_{\mathrm{p}}=5 \mathrm{~mm}$ resp. $15 \mathrm{~mm}$ the results are $\mathrm{Fx}_{(4000,1,5)}=$ $27.74 \mathrm{~N}, \mathrm{Fx}_{(4000,1,15)}=60.50 \mathrm{~N}$; it means the rate is 2.18 . For $\mathrm{Fx}_{(6000,1,5)}=21.25 \mathrm{~N}, \mathrm{Fx}_{(6000,1,15)}=43.55 \mathrm{~N}$; the rate is 2.04. The rate between $\mathrm{Fx}_{(4000,1,5)}=27.74 \mathrm{~N}$ and $\mathrm{Fx}_{(6000,1,5)}=21.25 \mathrm{~N}$ it is 1.3. The influence of revolutions is not so expressive, but it is by reason of smaller difference between the lowest and the highest value - 50\%; in case of axial and radial depth of cut it is $200 \%$.

For Fy and the same independent parameter the results are follows: $\mathrm{Fy}_{(4000,1,5)}=23.23 \mathrm{~N}, \mathrm{Fy}(4000,1,15)=$ $60.55 \mathrm{~N}$; it means the rate is 2.59 on the behalf of $\mathrm{Fy}_{(4000,1,15)}$. For $\mathrm{Fy}_{(6000,1,5)}=16.79 \mathrm{~N}, \mathrm{Fy}_{(6000,1,15)}=$ $43.48 \mathrm{~N}$; the rate is 2.58 on the behalf of $\mathrm{Fy}_{(6000,1,15)}$. The rate between $\mathrm{Fy}_{(4000,1,5)}=23.25 \mathrm{~N}$ and $\mathrm{Fy}_{(6000,1,5)}$ $=16.79 \mathrm{~N}$ it is 1.38 on the behalf of Fy(4000,1,5).

For follows technological conditions (rev. $4000 / \mathrm{min}$., resp. 6000 /min., $\mathrm{a}_{\mathrm{e}}=3 \mathrm{~mm}, \mathrm{a}_{\mathrm{p}}=5 \mathrm{~mm}$ resp. $15 \mathrm{~mm}$ the results are $\mathrm{Fx}_{(4000,3,5)}=78.59 \mathrm{~N}, \mathrm{Fx}_{(4000,3,15)}=198.69 \mathrm{~N}$; it means the rate is 2.52 on the behalf of $\mathrm{Fx}_{(4000,3,15)}$. For $\mathrm{Fx}_{(6000,3,5)}=56.82 \mathrm{~N}$, and for $\mathrm{Fx}_{(6000,3,15)}=145.50 \mathrm{~N}$ the rate is 2.56 on the behalf of 
$\mathrm{Fx}_{(6000,3,15)}$. The rate between $\mathrm{Fx}_{(4000,3,15)}=198.69 \mathrm{~N}$ and $\mathrm{Fx}_{(6000,3,15)}=145.50 \mathrm{~N}$ it is 1.36 on the behalf of $\mathrm{Fx}_{(4000,3,15) \text {. }}$

For Fy and the same independent parameter the results are follows: $\mathrm{Fy}_{(4000,3,5)}=44.24 \mathrm{~N}, \mathrm{Fy}(4000,3,15)=$ $128.93 \mathrm{~N}$; it means the rate is 2.91 on the behalf of $\mathrm{Fy}_{(4000,3,15)}$. For $\mathrm{Fy}_{(6000,3,5)}=30.41 \mathrm{~N}, \mathrm{Fy}_{(6000,3,15)}=$ $90.63 \mathrm{~N}$; the rate is 2.98 on the behalf of $\mathrm{Fy}_{(6000,1,15)}$. The rate between $\mathrm{Fy}_{(4000,3,5)}=44.24 \mathrm{~N}$ and $\mathrm{Fy}_{(6000,3,5)}$ $=30.41 \mathrm{~N}$ it is 1.45 on the behalf of Fy(4000,3,5).

\section{Acknowledgments}

This work was supported by the Slovak Research and Development Agency under the contract No. APVV-16-0177.

\section{References}

[1] D. C. Mongomery, Introduction to statistical quality control. John Wiley and Sons. 6th Edition. ISBN 978-0-470-16992-6. 2009. pp. 754.

[2] M. Kučerová. Uplatnenie metódy plánovania experimentov v manažérstve kvality. (Using methods of design of experiments in quality management). Trnava. AlumniPress. ISBN 97880-8096-112-1. 2010, pp. 92.

[3] M. Kučerová, H. Fidlerová, Improvement of a riveting process capability with application of tools and methods of the quality management". Applied Mechanics and Materials: Novel Trends in Production Devices and Systems. Vol. 474, ISSN 1660-9336, 2014, pp. 351-356.

[4] Ch. Anurattananon, et al., Optimisation using a central composite rotatable design for lacquer production process, Silpakorn U Science and Tech. J. 5 (2), 2011, pp. 10-45.

[5] D. Bajić, B. Lela, D. Živković, Modelling of machined surface roughness and optimization of cutting parameters in face milling, Metallurgy 47 (4), 2008, pp.331-334.

[6] D. Bajić, S. Jozić, L. Celent, Cutting force analysis in face milling using rotatable central composite design of experiments and Taguchi method. Strojarstvo 53 (4), 2011, ISSN $0562-$ 1887, pp. 243-248.

[7] E. R. Gunawan, D. Suhendra, Four-factors response surface optimization of the enzymatic systhesis of the wax ester from palm kernel oil. Indo. J. Chem., 8 (1), 2008, pp. 83-90.

[8] L. Javorek, J. Svoreň, M. Kučerová, Závislost' výslednej sily od otáčok a rýchlosti posuvu obrobku pri pílení buka (The dependence of results force from revolutions and feed speed during beech sawing). Acta Facultatis Technicae. Zvolen. ISSN 1336-4472. 22 (2), pp. 159167.

[9] S. P. Kondapalli, S. R. Chalamalasetti, N.R. Damera, Application of Taguchi based Design of Experiments to Fusion Arc Weld Processes, A Review. International Journal of Technology and Management. 2 (1), ISSN 1927-9000, 2013, pp. 1-8. 
[10] N. Alagumurthi, K. Palaniradja, V. Soundararajan, Optimization of Grinding Process Through Design of Experiment (DOE)-A Comparative Study Materials and Manufacturing Processes, 21 (1), 2006, pp. 19-21.

[11] A. Laure, Y. Altintas, Simulation of flank milling processes. Int. J. of Machine Tools and Manufacture 45, 2005, pp. 549-559.

[12] J. Monnin, F. Kuster, K. Wegener, Optimal control for chatter mitigation in milling - Part 1: Modeling and control design. Control Engineering Practice 24, 2014, pp. 156-166.

[13] A.C.C. Conceicao, C.F. Castro, J.P. Davim, Optimisation of multi-pass cutting parameters in face-milling based on genetic search. Int. J. Adv. Manuf. Technology 44, 2009, pp. 1106-1115.

[14] V.P. Astakov, V.V. Galitsky, Tool life testing in gundrilling: an application of the group method of data handling (GMDH). Int. J. of Machine Tools and Manufacture 45, 2005, pp. 509- 517.

[15] H. Coldwell, et al, Rapid machining of hardened AISI H13 and D2 moulds, dies and press tools. J. of Materials Processing Technology 135, 2003, pp. 301-3011.

[16] A. Velayudham, et al, Evaluation of drilling characteristics of high volume fraction fibre glass reinforced polymeric composite. Int. J. of Machine Tools and Manufacture 45, 2005, pp. 399406.

[17] K. Dong-W., Ch. Myeong-W., S. Tae-I, L. Eung-S., Application of Design of Experiment Method for Thrust Force Minimization in Step-feed Micro Drilling. Sensors 2008, 8, ISSN 1424-8220, pp. 211-221

[18] T.S. Lee, Y.J. Lin, A 3D Predictive cutting-force model for end milling of parts having sculptured surfaces, Int J Adv Manuf Technol. 16, 2000, pp. 773-783.

[19] N. Sharma, R. Khanna, R. Gupta, Multi Quality Characteristics of WEDM process parameters with RSM. Procesia Engineering 64, 2013, pp. 710-719.

[20] A.S. Shivade, V.D. Shinde, Multi-objective optimization in WEDM of D3 tool steel using integrated approach of Taguchi method \& Grey relational analysis. J Ind Eng Int (2014) 10:149-162.

[21] S. Krantikumar et al, Parameter optimization of CNC machining using Taguchi methodology. International Journal for Research in Applied Science and Engineering Technology 6 (IV), ISSN 2321-9653, 2018, pp. 4594-4598.

[22] G.W. Vickers, K.W. Quan, Ball-mills versus end-mills for curved surface machining. Transactions ASME Journal of Engineering for Industry, 111, 1989, pp. 22-26.

[23] T. Ozel, Y. Karpat, Predictive modelling of surface roughness and tool wear in hard turning using regression and neural networks. International Journal of Machine Tool and Manufacture 45, 2005, pp. 467-479.

[24] M. Nemec et al, Evaluation of structural isotropy of Cr-V ledeburitic steel made by powder metallurgy of rapidly solidified particles. Kovové materiály. (Metallic materials) 54 (6), ISSN 0023-432X, 2016, pp. 453-462. 
[25] K. Jemelniak, M. Nejman, D. Sniegulsky-Gradzka, Identification of dynamic cutting force coefficients by direct measurement of cutting forces during vibratory cutting. Journal of Machine Engineering. 16 (3), 2016, pp. 47-57. 